\title{
PENGENALAN BATIK PADA ANAK SEBAGAI WUJUD CINTA BUDAYA INDONESIA
}

\author{
Oleh: \\ Romy Setiawan ${ }^{1}$, Dyanningrum Pradhikta² \\ ${ }^{1}$ Seni Rupa Murni, FIB Universitas Brawijaya, \\ romybelajar@ub.ac.id
}

\begin{abstract}
Abstrak
Masa usia dini adalah masa keemasan bagi perkembangan kecerdasan setiap manusia, beragam hal menggugah rasa ingin tahu dan menantang keinginan berkesplorasi. Selama ini kegiatan seni di sekolah hanya sebatas menempel, mewarnai, dan menyanyi, yang diajarkan oleh guru kelas yang bukan memiliki ketrampilan khusus dalam bidang seni rupa. Sehingga melalui kegiatan pengenalan batik ini diharapkan dapat memberikan wawasan yang lebih tentang proses pembuatan batik serta menumbuhkan rasa cinta akan produk Indonesia sejak dini. Pengenalan batik pada anak dikemas dalam bentuk kegiatan workshop yang dibagi dalam tiga tahap, yaitu: 1) pemaparan materi tentang batik; 2) aplikasi desain sketsa untuk dijadikan batik, 3) apresiasi karya batik anak. Workshop ini memberikan keleluasaan bagi peserta didik untuk mengembangkan kreatifitas yang mereka miliki sesuai dengan bakat masing-masing. Proses dalam pembelajaran serta arahan dari tim pengabdian menjadi kunci untuk hasil akhir yang diinginkan, pemahaman peserta didik tentang proses pembuatan batik dikemas secara menarik sehingga memudahkan peserta didik dalam mengeksplor kreatifitasnya. Hasil kreativitas anak-anak ketika di alih mediakan dari gambar menjadi seni batik ternyata menarik secara visual dan menjadi lebih bernilai.
\end{abstract}

Kata Kunci: workshop, batik, anak

\begin{abstract}
Early childhood is a golden age for the development of the intelligence of every human being, various things arouse curiosity and challenge the desire to explore. So far, art activities in schools have only been limited to sticking, coloring, and singing, which are taught by class teachers who do not have special skills in the art field. So that through this batik introduction activity it is hoped that it can provide more insight into the process of making batik and foster a sense of love for Indonesian products from an early age. The introduction of batik to children is packaged in the form of workshop activities which are divided into three stages, namely: 1) presentation of material about batik; 2) application of sketch design to be made into batik, 3) appreciation of children's batik work. This workshop provides flexibility for students to develop the creativity they have in accordance with their respective talents. The learning process and direction from the service team are the keys to the desired final result, students' understanding of the process of making batik is packaged in an attractive manner making it easier for students to explore their creativity. The results of children's creativity, when converted from pictures to batik art, turned out to be visually attractive and became more valuable.
\end{abstract}

Keywords: workshop, batik, child

\section{PENDAHULUAN}

Batik adalah salah satu bentuk kearifan lokal karya seni asli Indonesia berupa kain. Batik adalah katya bangsa yang menyimpan nilai leluhur Indonesia dan diakui oleh bangsa lain, namun minat terhadap pemahaman batik itu sendiri masih kurang (Rachmawati, dkk, 2020). Sering terjadi kesalahpahaman tentang batik itu sendiri, yang mendapat pernghargaan dari UNESCO adalah batik tulis bukan batik cap atau printing. Jadi lebih pada prosesnya membatik yang dihargai sebagai pusaka kemanusiaannya. Batik sebagai karya kemanusiaan yang penuh dengan ragam kearifan lokal, tidak hanya dari motif saja tetapi juga proses pembuatannya. Terkait pemahaman yang salah tentang batik tersebut maka perlu mengenalkan dan mengedukasi baik dari segi produk maupun proses pembuatan batik tulis.

Lembaga pendidikan diharapkan berperan aktif dalam pelestarian batik tulis ini, dengan menambahkan kegiatan membatik dalam kegiatan pembelajaran. Langkah ini sudah banyak dilakukan sekolah-sekolah dan dinilai positif, sebagai bentuk motivasi guru dan siswa agar lebih mengenal melalui pembuatan karya batik tulis. 
TPA Aisiyah Malang merupakan salah satu lembaga Pendidikan Anak Usia Dini (PAUD) yang ditujukan bagi anak-anak sampai usia enam tahun. Dengan adanya pendidikan anak usia dini untuk mempersiapkan anak dengan memperkenalkan berbagai pengetahuan, sikap maupun perilaku kepada anak-anak dengan cara menyenangkan, karena pendidikan anak usia dini adalah tempat bermain yang nyaman (Ingkir dkk, 2020). Masa usia dini merupakan periode keemasan bagi perkembangan kecerdasan setiap manusia. Di usia dini, beragam hal menggugah rasa ingin tahu dan menantang keinginan berkesplorasi.

Metode pendidikan PAUD menunjang perkembangan secara holistik. Perkembangan anak secara holistik meliputi dimensi sosial, emosional, bahasa dan kognitif, fisik dan kreativitas. Salah satu metode pendidikan anak usia dini yang ditawarkan adalah melalui pendidikan seni rupa. Menurut Prayitno (2019) apresiasi dan kreasi dapat dikembangkan oleh peserta didik melalui pembelajaran seni dan keterampilan. Berdasarkan kondisi diatas, maka Kelompok Bermain TPA Aisiyah sekolah ini dipilih menjadi sasaran pengabdian. Selama ini kegiatan seni di sekolah hanya sebatas menempel, mewarnai, dan menyanyi, yang diajarkan oleh guru kelas yang bukan memiliki ketrampilan khusus dalam bidang seni rupa. Sehingga melalui kegiatan pengenalan batik ini diharapkan dapat memberikan wawasan yang lebih tentang proses pembuatan batik serta menumbuhkan rasa cinta akan produk Indonesia sejak dini. Melalui kegiatan ini diharapkan anak mampu mengenal dan memahami tentang batik, tidak hanya produk tetapi juga proses pembuatannya.

\section{METODE}

Pada pengabdian ini dilaksanakan untuk peserta didik di TPA Aisiyah Kabupaten Dau Malang. Taget dari kegiatan ini adalah mengenal batik, mengetahui proses pembuatan batik tulis dan praktik belajar membuat batik. Metode yang digunakan adalah ceramah, demonstrasi dan pelatihan. Pelaksanaan kegiatan pengabdian dalam bentuk workshop batik tulis dibagi dalam tiga tahap, yaitu: 1) pemaparan materi tentang batik; 2) aplikasi desain sketsa untuk dijadikan batik, 3) apresiasi karya batik anak. Workshop ini memberikan keleluasaan bagi peserta didik untuk mengembangkan kreatifitas yang mereka miliki sesuai dengan bakat masing-masing. Peserta didik dibekali tentang pengetahuan dan wawasan terkait batik tulis dan proses pembuatannya.

Menurut Prasetyo (2016:51) Batik tulis adalah kain yang dihias dengan tekstur dan corak batik menggunakan tangan; dikerjakan dengan menggunakan canting. Dalam kegiatan ini, murid didampingi tim pengabdian akan mempelajari langsung proses pembuatan batik tulis, dimulai dari pembuatan sketsa, mencanting, mewarnai dan melorot. Untuk teknik batik yang dipilih adalah teknik titik lilin dimana teknik ini merupakan teknik sederhana yang dapat diaplikasikan oleh anakanak. Peserta didik akan berkarya batik dengan media yang disediakan oleh tim pengabdian, di samping itu peserta didik juga mendapat penggalaman mempresentasikan dan mengapresiasi karya.

Persiapan utama dalam kegiatan pengabdian ini adalah mempersiapkan materi dan media penunjang workshop. Adapun materi yang dipersiapkan untuk peserta didik adalah mengenai alat dan bahan dalam proses pembuatan batik antara lain: kain prisma, malam, canting, kompor dan wajan batik. Sebagai media edukasi untuk peserta didik TPA Aisyiyah, tim pengabdian mempersiapkan beberapa contoh batik dengan berbagai warna dan motif sederhana, serta batik shibori. Untuk memperlihatkan proses tahapan membatik yaitu mola dan mencanting, tim pengabdian juga mempersiapkan sehelai kain yang sudah dilengkapi dengan sketsa motif dan hasil canting malam.

\section{HASIL DAN PEMBAHASAN}

Pembelajaran batik pada anak usia dini juga pernah dilakukan oleh Sri Yunimar dkk (2019), yaitu Pembelajaran Batik Dari Wortel Sebagai Alternatif Teknik Membatik Sederhana Anak Usia Dini Di Taman Kanak-Kanak. Batik dari wortel adalah teknik membatik pada kain dengan menggunakan media wortel sebagai media untuk menghasilkan motif (pengganti canting). Batik diajarkan melalui versi sederhana, baik alat, bahan ataupun teknik. pembelajaran batik pada anakanak sangatlah perlu, walaupun tidak dipraktekkan secara detail seperti batik tulis. Hal ini berbeda dengan pengabdian yang dilakukan yaitu mengenalkan batik melalui workshop batik tulis. Pertimbangan kerumitan dan ketrampilan dalam pembuatan batik tulis buka menjadi fokus utama, tapi bagaimana batik dikenalkan sejak dini. Sehingga anak mampu mengenal dan memahami tentang batik, tidak hanya produk tetapi juga proses pembuatannya, melalui pembelajaran yang menarik dan menyenangkan.

Rangkaian kegiatan pengabdian difokuskan pada workshop proses pembuatan batik tulis bagi peserta didik TPA Aisyiyah. Dengan pertimbangan usia peserta didik TPA Aisiyah dan waktu pelaksanaan yang disesuaikan dengan jam belajar serta kapasitas anak. Secara umum, kegiatan pengabdian berjalan dengan baik dan lancar. Berikut deskripsi realisasi kegiatan pengabdian di TPA Aisyiyah:

\section{Penyampaian Materi Batik}

Kegiatan pengabdian dimulai pukul 08.30 WIB. Peserta yang terlibat dan hadir dalam kegiatan ini berjumlah 15 peserta didik dan didampingi 4 guru. Sebelum kegiatan pemarapan materi dimulai, peserta didik diajak bernyanyi sambal tepuk tangan untuk membangkitkan semangat pagi. Dalam acara 
ini, peserta didik yang terlibat antusias mendengarkan materi yang disampaikan oleh tim pengabdian. Acara ini berlangsung komunikatif dua arah, tentunya juga dengan pendampingan dari guru. Tim pengabdian memberikan materi tentang wawasan batik, alat bahan batik, macam-macam batik, contoh hasil batik, dan sedikit pemaparan tentang proses pembuatan batik. Diskusi berjalan dengan lancar, terlihat dari beberapa pertanyaan dari peserta didik dan juga guru.

Selanjutnya, terdapat sesi praktek yang ditujukan untuk peserta didik yang terlibat. Praktek yang diberikan berupa menggambar sketsa motif batik. Peserta didik diberikan media gambar berupa kertas dan spidol, dimana mereka diberikan kebebasan untuk berekspresi. Pada sesi ini peserta didik menggambar langsung menggunakan spidol. Peserta yang terlibat sangat antusias mengikuti kegiatan ini sampai selesai; seperti pada gambar 1 dibawah ini.

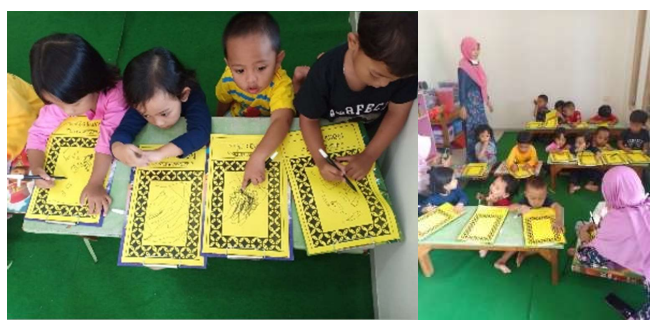

Gambar 1. Sesi Praktek Gambar Sketsa

Setelah kira-kira satu jam hasil karya peserta didik selesai dan dikumpulkan. Kertas hasil menggambar kemudian dikumpulkan dan kemudian tim pengabdian memberikan apresiasi dengan menanyakan judul dan maksud dari hasil gambar masing-masing peserta didik. Dari hasil gambar yang didapatkan memang tidak keseluruhan sudah terlihatnya bentuknya, namun disinilah keunikan karakteristik gambar anak, contohnya seperti pada gambar 2 dibawah ini.

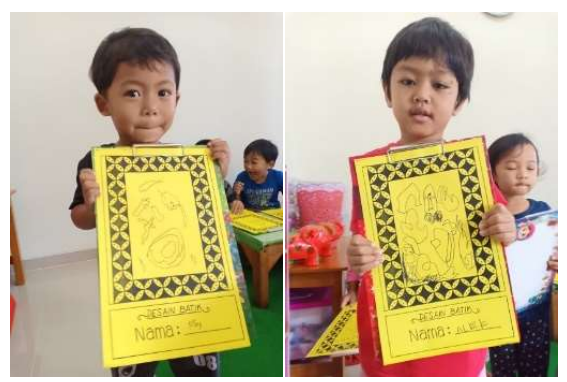

\section{Gambar 2. Hasil Gambar Sketsa}

Peserta didik di TPA Aisyiyah yang mengikuti kegiatan ini berusia 3-6 tahun. Menurut Victor Lowenfeld mengenai perkembangan gambar anak yang ditulis dalam buku Creative and Mental Growth adalah tahapan mencoreng, pra bagan, bagan, permulaan realisme, dan naturalistik semu (Loita, 2017). Hasil gambar dari peserta didik di TPA Aisyiyah dapat dikelompokkan dalam 2 kelompok yaitu; 1) scribbling stages/mencoreng (2-4 tahun); dan 2) preschematic stages/pra bagan (4-7 tahun). Apabila disimpulkan hasil visualnya berupa goresan-goresan tegak, mendatar, lengkung bahkan lingkaran, coretan dilakukan berulangulang. Ada pula yang visualnya mulai terwujud menjadi satu kesatuan, bentuk yang semakin bervariasi, dan ada pula yang mulai menggambar bentuk-bentuk yang berhubungan dengan dunia sekitar mereka seperti gambar rumah.

\section{Aplikasi Batik}

Kegiatan aplikasi batik ini terpaksa dibatalkan, hal ini mempertimbangkan kondisi dan situasi di lingkungan TPA Aisyiyah yang mengkhawatirkan karena adanya kasus Covid 19 disekitar lingkungan sekolah. Adanya pembatasan baik dari sisi jumlah peserta didik yang masuk, dan juga aktivitasnya, serta untuk mengurangi resiko anak-anak berkerumun dan menggunakan alat secara bergantian, kegiatan aplikasi desain sketsa untuk dijadikan batik tidak memungkinkan untuk dilaksanakan oleh peserta didik di TPA Aisyiyah. Kegiatan aplikasi batik ini dibantu oleh tim pengabdian kepada masyarakat, dengan tetap mengacu pada gambar sketsa motif batik yang sudah digambar peserta didik pada kegiatan sebelumnya.

Proses aplikasi batik ini melalui beberapa tahap, antara lain: Pencucian kain prisma berukuran $30 \times 30 \mathrm{~cm}$ yang akan dijadikan media membatik. Sebelum prosess membatik, dilakukan mordanting kain (perebusan dengan tawas dan soda ash). Selanjutnya kain tersebut dipotong dan di neci/ bis tepi keliling kain, dan kemudian proses 'nyorek' atau tracing pola ke atas kain primis sesuai gambar sketsa motif peserta didik. Pola tersebut digambar menggunakan pensil untuk memudahkan saat nglowong/ nyanting dengan malam. Proses selanjutnya menorehkan malam batik ke kain sesuai motif, termasuk motif isen-isen. Teknik pewarnaan batik dengan menggunakan naptol, Setelah proses pewarnaan selesai selanjutnya dilakukan proses pelorotan malam dari kain. Ini dilakukan dengan cara merebus kain dalam panci berisi air panas, dengan tujuan 
kain betul-betul bersih dari malam, untuk selanjutnya kain diangin-anginkan.

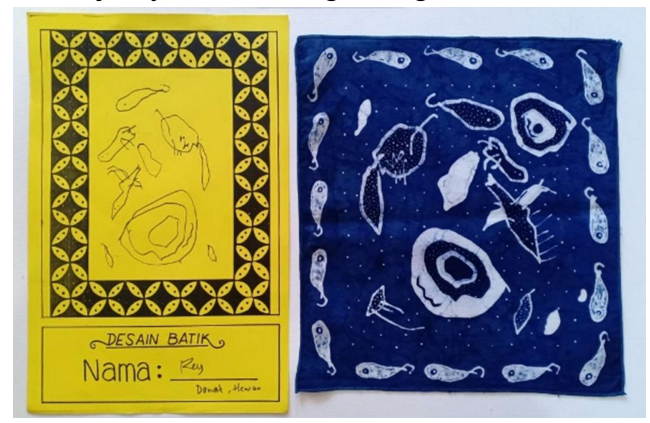

Gambar 3. Hasil Karya Batik

Pada tahap aplikasi batik ini membutuhkan waktu sedikit lama karena prosesnya yang bertahap. Jumlah gambar sketsa yang diaplikasikan menjadi batik adalah sejumlah 18 buah, dengan karakteristik gambar masing-masing anak. Pada gambar 3 adalah contoh hasil karya batik Reynand, dengan sketsa berupa garis goresan lengkung dan bentuk yang beragam. Setalh diaplikasn pada karya batik ditambahkan motif tumpal/ pinggiran. Warna yang digunakan untuk warna monokrom biru, agar hasil gambar sketsa motif yang sudah jadi batik lebih menonjol.

\section{Apresiasi Batik}

Kegiatan apresiai batik berlangsung selama kurang lebih 2 jam, tentunya dengan menerapkan protokol kesehatan sebelum melaksanakan pengabdian. Peserta yang terlibat dan hadir dalam kegiatan ini berjumlah 9 peserta didik dan didampingi 3 guru. Acara diawali dengan penyampaian materi tentang proses pembuatan batik dan peserta didik di ajak untuk mengingat kegiatan sebelumnya yaitu proses menggambar sketsa. Acara ini berlangsung komunikatif dua arah, tentunya juga dengan pendampingan dari guru. Respon positif dari peserta didik dan guru terlihat melalui ekspresi. Kegiatan mengapresiasi karya seni sangat penting dalam upaya mendapatkan pengalaman estetik dan mengembangkan kepribadian siswa (Rondhi, 2017). Selain memberikan ruang bagi anak untuk menceritakan hasil karyanya, ruang apresiasi ini juga menjadi wadah anak untuk belajar berkomunikasi dan mengharagai hasil karya masing-masing. Terlihat pada gambar 4, peserta didik meceritakan gambar yang sudah dibuat kepada teman-teman dan guru.

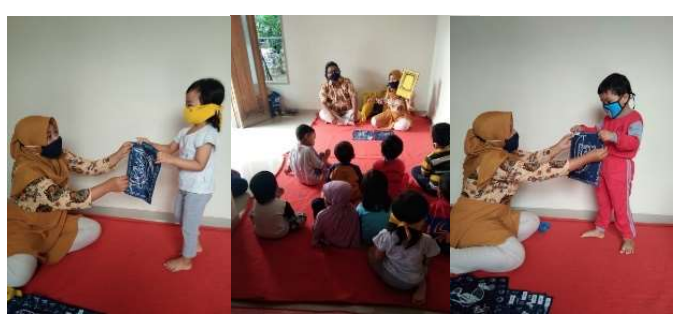

Gambar 4. Apresiasi Karya Batik Anak

Selain itu proses menciptakan batik beserta diskusi apresiasi karya menjadi penting sebagai media, dimana ketika proses pembelajaran formal minim sekali terkait wadah apresiasi karya seni anak. Sehingga karya seni tidak hanya berhenti pada pajangan dan lomba. Pada dasarnya tidak ada ukuran objketif yang bisa digunakan untuk mengukur kualitas kekaryaan anakanak, karena seni rupa tidak seperti olahraga atau sains yang bisa diukur secara kuantitatif, kecuali dalam perpesktif disiplin pokok perupaan realis. Dalam psikologi perkembangan anak, di usia tersebut seorang anak pada umumnya belum sampai pada logika bentuk 3 dimensi realisme, karena mereka menggambar berdasarkan apa yang dia lihat atau yang mereka bayangkan.

\section{SIMPULAN DAN SARAN}

Melalui kegiatan ini, menjadi cara yang efektif dalam proses edukasi anak, memberikan pengetahuan tentang batik, belajar proses membatik dan mengapreasiasi karyanya. Tentunya anak-anak akan merasa bangga dengan hasil kreativitas mereka. Hal ini juga terlihat pada respon positif para pengajar dan orang tua wali, yang tidak menduga bahwa hasil kreativitas anak-anak ketika di alih mediakan dari gambar menjadi seni batik ternyata menarik secara visual dan menjadi lebih bernilai. Harapan dari kegiatan ini, anak-anak akan semakin bersemangat dalam berdaya kreativitas seni rupa, untuk menghasilkan produk-produk baru yang indah. Bagi guru, melalui kegiatan ini mendapat perspektif bandingan untuk mengembangkan metode pembelajaran kepada peserta didiknya. Melalui hasil karya seni anak, setidaknya orang tua wali dapat membangun komunikasi pada ruang apreasi karya anak. Karena pada perkembangannya proses kreativitas berkesenian anak tidak 
kalah penting dengan pelajaran lainnya seperti membaca, menulis maupun menghitung. Sehingga pada akhirnya aspek kognitif, psikomorik dan afektif anak berkembang sesuai tahapan usianya.

Pengenalan batik pada usia dini lebih bermakna melalui pembelajaran sekaligus praktek, oleh karena itu kegiatan seperti ini mencari wacana untuk tetap dikembangkan dalam skala yang lebih luas. Dari hasil kegiatan ini pula bisa membuka peluang untuk dijadikan sebuah penelitian tentang batik dan anak. Begitupun untuk pihak sekolah TPA Aisyiah untuk tetap mengembangkan metode pembelajaran seni dan turut memperkenalkan karya seni bangsa sejak dini.

\section{DAFTAR PUSTAKA}

Ingkir, Yuni, dkk. 2020. Kegiatan Membatik Dalam Mengembangkan Kemampuan Motorik Halus Anak. Jurnal Pendidikan Guru Pendidikan Anak Usia Dini, Vol 3 No 1.

Loita, Aini. 2017. Karakteristik Pola Gambar Anak Usia Dini. Early Chiidhood: Jurnal Pendidikan, Vol 1 No 1.

Ningsih, Sri Yunimar dan Mayar, Farida. 2019. Pembelajaran Batik dari Wortel sebagai Alternatif Teknik Membatik Sederhana Anak Usia Dini di Taman Kanak-Kanak. Jurnal Pendidikan Tambusai, Vol 3 No 6 (1403-1407).

Prasetyo, Adhi dan Singgih. 2016. Karakteristik Motif Batik Kendal Interpretasi dari Wilayah

dan Letak Geografis. Semarang: Jurnal Imajinasi Unnes Vol. X No. 1.

Prayitno. 2019. Pembelajaran Batik Tetes Lilin Sebagai Alternatif Teknik Membatik Sederhana Pada Mahasiswa PAUD. Jurnal Pendidikan Anak, Vol 8 No 1.

Rachmawati, Emma, dkk. 2020. Pengenalan Batik Indonesia Menggunakan Ciri Warna dan Tekstur. IJAI Indonesian Journal of Applied Informatics, Vol 4 No 2.

Rondhi, Moh. 2017. Apresiasi Seni dalam Konteks Pendidikan Seni. Jurnal Imajinasi Unnes Vol XI no 1. 